ISSN: $1412-4734$

E-ISSN: 2407-8646

Volume 17, Number 2, 2017

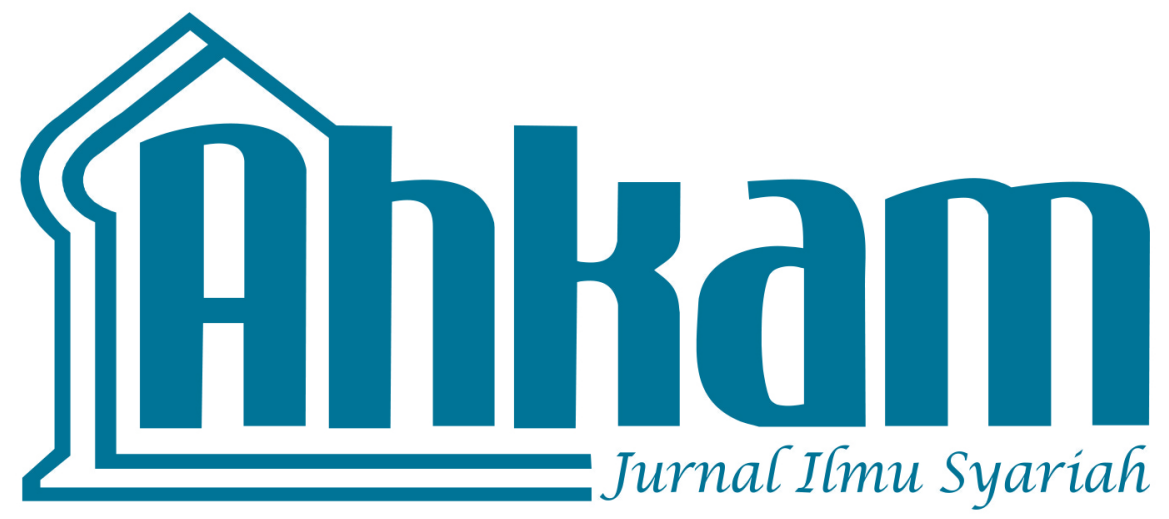

* M. Arskal Salim GP

Competing Political Ideologies on the Implementation of Islamic Law in Indonesia: Historical and Legal Pluralist Perspectives

* Atang Abd Hakim, Hasan Ridwan, M. Hasanuddin, Sofian AL-Hakim

Towards Indonesia Halal Tourism

* Dewi Sukarti

Customary Law of Inheritance and Migration: Adoption of the Old Regime or Adaptation to the New One?

* Jaenal Effendi \& Anggita Aulia Pratiwi

Factors Affecting the Repayment Rate of Mushäraka Financing on Micro Enterprises: Case Study of BMT Al Munawwarah, South Tangerang

* Rusli Hasbi

Al-Muzāharāt al-Silmiyyah Tatbīqan li Nizām al-Riqābah al-Sha biyyah fi al-Fiqh al-Islāmī wa al-Qānūn al-Waḍ '̄i al-Indūnīsī

* Daud Rasyid \& Aisyah Daud Rasyid

Ribā al-Qarḍ fi al-Muāmalāt al-Mu'āṣirah fi Mīzān al-Iqtiṣād al-Islāmī 


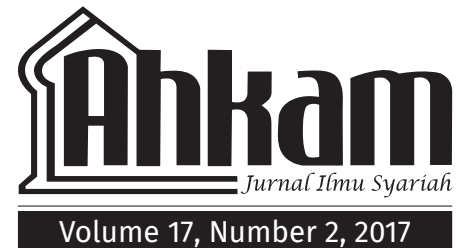

\author{
EDITOR-IN-CHIEF \\ Khamami Zada

\section{EDITORS} \\ Ahmad Tholabi Kharlie \\ Fathuddin \\ Maman R Hakim \\ Ahmad Bahtiar
}

\title{
INTERNATIONAL EDITORIAL BOARD
}

Tim Lindsey (University of Melbourne Australia)

Nadirsyah Hosen (Monash University Australia)

Ahmad Hidayat Buang (Universiti Malaya Malaysia)

Raihanah Azahari (Universiti Malaya Malaysia)

Mark Elwen Cammack (Southwestern University)

Razeen Sappideen (University of Western Sydney)

Carolyn Sappideen (University of Western Sydney)

Nik Ahmad Kamal bin Nik Mahmod (International Islamic University Malaysia)

Muhammad Atho Mudzhar (UIN Syarif Hidayatullah Jakarta)

Masykuri Abdillah (UIN Syarif Hidayatullah Jakarta)

Muhammad Amin Suma (UIN Syarif Hidayatullah Jakarta)

M. Arskal Salim GP (UIN Syarif Hidayatullah Jakarta)

Asep Saepudin Jahar (UIN Syarif Hidayatullah Jakarta)

\section{ASSISTANT TO THE EDITORS}

M. Ishar Helmy

Erwin Hikmatiar

ENGLISH LANGUAGE ADVISOR

Bradley Holland

Umi Kulsum

ARABIC LANGUAGE ADVISOR

Amany Burhanuddin Lubis

AHKAM has been accredited based on the determination of Director General of Research Reinforcement and Development, Research, and Technology Ministry of Higher Education of Republic of Indonesia, No. 36/a/E/KPT/2016 (valid until 2021). 
AHKAM Jurnal Ilmu Syariah (ISSN: 1412-4734) is a periodical scientific journal published by Faculty of Sharia and Law of Syarif Hidayatullah State Islamic University Jakarta in collaboration with Indonesian Scientist and Sharia Scholar Association (HISSI). This journal specifically examines the science of sharia and obtains to present various results of current and eminence scientific research. The administrators receive articles as contributions Sharia and Islamic law disciplines from scientists, scholars, professionals, and researchers to be published and disseminated.

\section{EDITORIAL OFFICE:}

Fakultas Syariah dan Hukum UIN Syarif Hidayatullah Jakarta

Jl. Ir. H. Juanda 95 Ciputat, Jakarta 15412

Telp. (+62-21) 74711537, Faks. (+62-21) 7491821

Website: http://journal.uinjkt.ac.id/index.php/ahkam/index

E-mail: Jurnal.ahkam@uinjkt.ac.id 


\section{TABLE of Contents}

259 M. Arskal Salim GP

Competing Political Ideologies on the Implementation of Islamic Law in Indonesia: Historical and Legal Pluralist Perspectives

279 Atang Abd Hakim, Hasan Ridwan, M. Hasanuddin, Sofian Al-Hakim

Towards Indonesia Halal Tourism

301 Dewi Sukarti

Customary Law of Inheritance and Migration: Adoption of The Old Regime or Adaptation to The New One? 301

321 Jaenal Effendi \& Anggita Aulia Pratiwi

Factors Affecting The Repayment Rate of Musharaka Financing on Micro Enterprises: Case Study of BMT Al Munawwarah, South Tangerang

335 A. BAKIR IHSAN

Kebijakan Berdimensi Syariah dalam Sistem Partai Politik Islam 
351 M. Beni Kurniawan

Pembagian Harta Bersama Berdasarkan Kontribusi dalam Perkawinan

373 Salnuddin

Indikator Penciri Penanggalan Hijriah pada Pergerakan Pasang Surut

389 Moh. Ali Wafa

Telaah Kritis Terhadap Perkawinan Usia Muda Menurut Hukum Islam

413 JA'FAR

Al Jam'iyatul Washliyah dan Problem Kepemimpinan Non Muslim dan Perempuan

435 Saut Maruli Tua Manik, Yaswirman, Busra Azheri, IKHWAN

Penyelesaian Sengketa Ekonomi Syariah Melalui Pengadilan Khusus Ekonomi Syariah di Lingkungan Peradilan Agama

449

$$
\text { والقانون الوضاهرات السلمية تطبيقا لنظام الرقابة الشعبية في الفقه الإسلامي حسبي }
$$

داود راشد وعائشة داود راشد

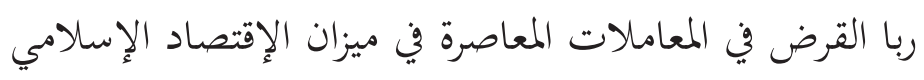




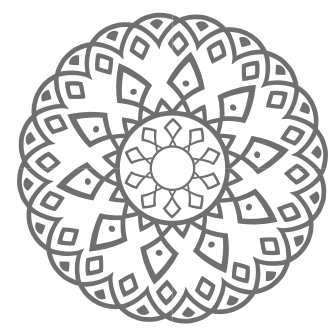

\title{
Pembagian Harta Bersama Berdasarkan Kontribusi dalam Perkawinan
}

\author{
M. Beni Kurniawan
}

\begin{abstract}
Abstact: This article describes marital property issues. How to devides marital property that can give justice to the parties. Becaused of that, this article provides a concept that can give justice to the parties ie marital property's distribution based on contributions in marriage. This concept is regarded more fair than the concept that provided by KHI. This study also gives religious court's judges opinion about the concept of marital property's distribution based on contributions in marriage. This article concludes that the concept of marital property's distribution based on contributions in marriage is the distribution of marital property by assessment the contribution of the parties. In marital properties cases, if one party gives more contribution than the others, The judge can do contra legem. So that in casuistic, The distribution must not be $50 \%$ maybe the widower get $25 \%$ and the widow get $75 \%$ depend on their contributions.
\end{abstract}

Keywords: marital property, contributions in marriage, religious court's judges opinion 
Abstrak: Artikel ini menjelaskan pembagian harta bersama yang dapat memberikan keadilan bagi para pihak. Tulisan ini menawarkan sebuah konsep pembagian berdasarkan kontribusi dalam perkawinan yang dinilai lebih adil bagi para pihak ketimbang aturan pembagian harta bersama yang terdapat di dalam Kompilasi Hukum Islam. Selain itu, studi ini juga memberikan pandangan hakim Pengadilan Agama mengenai konsep pembagian harta bersama berdasarkan konstribusi di dalam perkawinan. Artikel ini menyimpulkan bahwa pembagian harta bersama berdasarkan kontribusi adalah pembagian harta bersama dengan menilai besaran kontribusi para pihak. Dalam perkara harta bersama yang salah satu pihak mempunyai kontribusi yang lebih besar hakim diperkenankan untuk melakukan cotra legem.

Kata kunci: harta bersama, adil, hakim, perkawinan

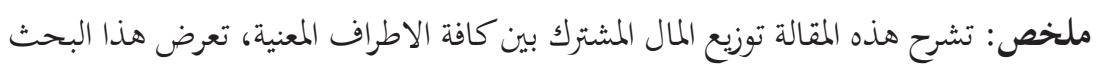

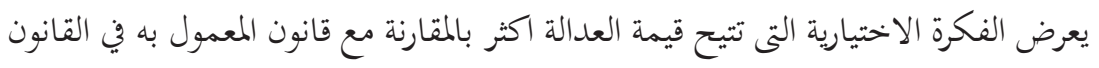

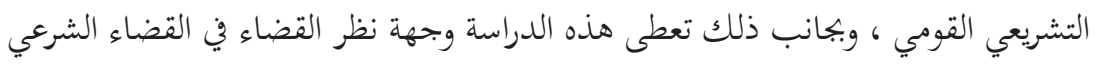

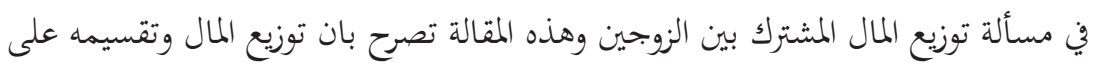

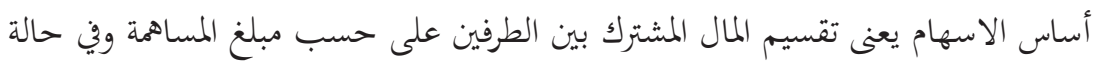

$$
\begin{aligned}
& \text { المال المشترك فان القاضى يمكن له قضاء لصاحب الاسهام الاكبر. } \\
& \text { الكلمات المفتاحية: المشترك، العادل، القاضي }
\end{aligned}
$$




\section{Pendahuluan}

Perkawinan merupakan sebuah instansi yang mengandung multi aspek dan multi dimensi (Hakim, 2000: 146). Antara aspek yang satu dengan aspek yang lain berjalan merata tidak mendominasi. Aspek tersebut antara lain aspek sosial, aspek ritual, aspek moral dan aspek kultural. Dengan aspek yang terkandung dalam institusi tersebut mengandung tanda (qarinah) bahwa perkawinan merupakan suatu persekutuan suci yang tinggi nilainya di dalam Islam. Oleh sebab itu hendaklah perkawinan dihindari dari segala hal yang bisa merusak nilai dari sebuah perkawinan

Kenyataan membuktikan banyak faktor yang memicu keretakan bangunan rumah tangga. Dengan putusnya suatu perkawinan maka menimbulkan akibat hukum yang merupakan konsekuensi dari hubungan antara suami dan istri. Akibat hukum yang ditimbulkan adalah hak asuh anak (hadanah), nafkah iddah dan mut'ah, masa iddah istri, nafkah istri dan anak, dan harta bersama (Mulyo, 1985: 212-213). Harta bersama merupakan hasil dari hubungan hukum kekeluargaan dan hubungan hukum kekayaannya terjalin sedemikian eratnya sehingga keduanya tidak dapat dipisahkan (Satrio, 1991: 5). Oleh sebab itu, dengan putusnya perkawinan maka harta bersama yang diperoleh harus dibagi di antara suami dan istri.

Perihal mengenai harta bersama diatur dalam Undang-Undang Perkawinan No.1 Tahun 1974 yang mengatur tentang harta perkawinan, pada bab VII dalam judul harta bersama dalam perkawinan. Dalam pasal 36 dijelaskan bahwa harta bersama adalah harta benda yang diperoleh selama perkawinan menjadi harta bersama. Harta bersama dibagi apabila terjadi perceraian dalam perkawinan. Kenyataan yang terjadi setiap perceraian yang terjadi selalu menimbulkan sengeketa antara suami dan istri yang menuntut hak mereka masing-masing sehingga sering terjadi gugatan harta bersama yang diajukan di pengadilan agama.

Mengenai pembagian harta bersama atau gono-gini, dalam Kompilasi Hukum Islam pasal 97 disebutkan bahwa janda atau duda cerai masingmasing berhak seperdua atas harta peninggalan bersama selama tidak ditentukan lain dalam perjanjian pernikahan. Kemudian dalam pasal 128129 KUHPer dinyatakan bahwa apabila putusnya tali perkawinan antara suami dan istri maka harta bersama itu dibagi dua antara suami-istri. 
Aturan Kompilasi Hukum Islam dan KUHPer tentang harta bersama yang dibagi dua dengan besaran yang sama banyak telah memberikan keseimbangan hak kepada pihak laki-laki dan perempuan. Pembagian yang sama rata akan menjadi pembagian yang adil apabila suami isteri memberikan besaran kontribusi yang sama selama perkawinan. Suami melaksanakan kewajibannya dengan mencari nafkah dan istri melaksanakan kewajibannya dengan mengurus rumah tangga. Namun tidak sedikit dalam suatu rumah tangga salah satu pihak tidak melaksanakan kewajibannya sehingga menimbulkan adanya kontribusi yang tidak seimbang antara suami istri, baik kontribusi suami lebih besar dari pada istri, maupun kontribusi istri lebih besar dari pada suami atau hanya salah satu pihak yang berkontribusi di dalam proses penciptaan harta bersama, sedangkan pihak lain hanya menjadi beban terhadap pihak lain.

Fenomena terhadap kontribusi yang tidak seimbang di dalam pengumpulan harta bersama dapat dijumpai dalam kehidupan nyata. Misalnya apa yang penulis temukan tentang gugatan harta bersama yang terjadi di Pengadilan Agama Bukit Tinggi. Dalam gugatan tersebut seorang suami menggugat mantan istrinya terhadap pembagian harta bersama untuk dibagi setengah sama banyak sesuai ketentuan Kompilasi Hukum Islam.

Adapun isteri atau (tergugat) berpandangan bahwa harta yang diperoleh selama perkawinan adalah hasil jerih payahnya dimana tergugatlah yang lebih dominan dan berperan aktif dalam memenuhi kebutuhan hidup rumah tangganya. Hal ini dapat dilihat dari kegigihan isteri dalam memenuhi kehidupan rumah tangganya, sementara suami (penggugat) bekerja atas apa yang sudah diusakan oleh tergugat sebelumnya. Selain isteri (tergugat) bekerja dalam rumah tangga sifatnya hanya meringankan beban suami (penggugat), bukan sebagai tulang punggung untuk memenuhi kelangsungan hidup berumah tangga. Padahal seharusnya suamilah yang berkewajiban mencari nafkah sebagaimana yang diatur dalam pasal 80 ayat (4) huruf a dan b Kompilasi Hukum Islam yang menyatakan bahwa kewajiban seorang suami terhadap istrinya adalah (1) Nafkah, kiswah dan tempat kediaman bagi isteri, (2) Biaya rumah tangga, biaya perawatan dan biaya pengobatan bagi isteri dan anak.

Berdasarkan latar belakang masalah di atas, maka menurut penulis 
perlu diangkat permasalahan, yaitu (1) Bagaimana pembagian harta bersama berdasarkan kontribusi dalam perkawinan; (2) Bagaimana pandangan hakim Pengadilan Agama Bukit Tinggi tentang pengaruh kontribusi dalam perkawinan terhadap bagian pada harta bersama?

\section{Harta Bersama}

Menurut Sayuti Thalib, harta bersama adalah harta kekayaan yang diperoleh selama perkawinan di luar hadiah atau warisan. Maksudnya adalah harta yang didapat atas usaha mereka atau sendiri-sendiri selama masa ikatan perkawinan (Thalib, 1986: 85). Adapun pengertian harta bersama dalam UU Perkawinan No.1 Tahun 1974 pasal 35 adalah harta yang diperoleh selama perkawinan menjadi harta bersama”

Di berbagai daerah di tanah air, terdapat berbagai istilah tentang harta bersama. Misalnya di Jawa dikenal dengan nama "harta gonogini”. Masyarakat Aceh mengenal dengan istilah 'hareuta sihareukat". Masyarakat Minangkabau mengenal dengan istilah "harta suarang" dan lain sebagainya (Harahap, 1997: 298). Perbedaan tersebut hanya dari segi namanya saja, namun pada hakikatnya adalah sama. Kesamaan ini terletak dari benda suami isteri yang dijadikan sebagai harta bersama.

Di dalam Alquran dan Hadis tidak ditemui konsep tentang harta bersama dalam perkawinan. Hukum Islam hanya mengenal pemisahan harta. Harta kekayaan isteri menjadi milik isteri dan dikuasai penuh olehnya dan harta suami milik suami dan dikuasai penuh olehnya. Dalam kitab-kitab fikih pun tidak dibahas mengenai harta bersama.

Tidak adanya pembahasan harta bersama secara komprehensif oleh para fukaha diakui juga oleh Prof. Dr. Bustanul Arifin, SH. Beliau menyebutkan hal tersebut disebabkan karena pemahaman syariat waktu kitab-kitab fikih tersebut ditulis dan keadaan susunan masyarakat pada waktu itu belum mengenal konsep harta bersama (Arifin, 1996: 122).

Sedangkan di Indonesia harta bersama dikenal melalui hukum adat yang diterapkan secara terus menerus sebagai hukum yang hidup. Oleh sebab itu, lembaga harta bersama tidak mungkin untuk disingkirkan karena lebih besar mashlahatnya dari pada mudharatnya. Atas dasar metodologi mașlahah mursalah, urf, dan kaidah al-ädah almuhakkamah (adat dapat menjadi hukum).

Para ulama melakukan pendekatan kompromistis kepada hukum 
adat. Selain pendekatan kompromistis, Prof. Ismuha dalam disertasinya telah mengembangkan pendapat pencaharian bersama suami isteri mestinya masuk dalam rub' muamalat tetapi secara khusus tidak dibicarakan. Mungkin hal ini disebabkan karena pada umumnya pengarang dari kitab-kitab tersebut adalah orang Arab, sedangkan adat Arab tidak mengenal adat harta bersama. Tetapi di sana dibicarakan mengenai mată al-bayt dan masalah perkongsian yang dalam bahasa arab disebut shirkah (Ismuha, 1986: 282).

Adapun Hadis mengenai shirkah diriwayatkan dari Abu Hurairah bahwa Rasulullah Saw bersabda:

Sesungguhnya Allah Swt. telah berfirman: "Aku adalah mitra ketiga dari dua orang yang bermitra selama salah satu dari kedunya tidak mengkhianati yang lainnya. Jika salah satu dari keduanya telah mengkhianatinya maka Aku keluar dari perkongsian itu”. (H.r. Abu Dawud dan al-Hakim).

Arti Hadis ini adalah bahwa Allah Swt akan selalu bersama kedua orang yang berkongsi dalam kepengawasan-Nya, penjagaan-Nya dan bantuan-Nya. Allah akan memberikan bantuan dalam kemitraan ini dan menurunkan berkah dalam perniagaan mereka. Jika keduanya atau salah satu dari keduanya telah berkhianat maka Allah meninggalkan mereka dengan tidak memberikan berkah dan pertolongan sehingga perniagaan itu merugi (Huda, 2010:67).

Macam-macam shirkah menurut para ulama ada lima macam:, pertama shirkah inān, yaitu perkongsian antara dua orang atau lebih dimana masing-masing mempunyai modal dan sama-sama bekerja menjalankan usaha akan tetapi tidak harus sama dalam hal modal dan tenaganya. Keuntungan dibagi sesuai dengan perjanjian waktu perkongsian dibentuk. Mengenai macam shirkah ini para ulama mazhab sepakat tentang bolehnya (Sâbiq, 1987: 197).

Kedua, shirkah mufāwadah, yaitu kerja sama antara dua orang atau lebih. Setiap pihak memberikan suatu porsi dari keseluruhan dana dan berpartisipasi dalam kerja. Setiap pihak membagi keuntungan dan kerugian secara sama. Shirkah mufäwadah juga merupakan shirkah komprehensif yang dalam shirkah itu semua anggota sepakat melakukan aliansi dalam semua jenis kerja sama, seperti 'inân, abdân dan wujûh. Dengan demikian, syarat utama dari shirkah ini adalah kesamaan dalam dana (modal) yang diberikan, kerja, tanggung jawab, 
beban utang dibagi oleh masing-masing pihak, dan agama.

Ketiga, shirkah abdān, beberapa orang tukang atau pekerja bekerja sama melakukan pekerjaan dengan keuntungan dibagi menurut perjanjian. Hukum shirkah ini boleh menurut mazhab Hanafi, Maliki dan Hanbali. Meskipun ketiga mazhab tesebut membolehkan akan tetapi mereka berbeda mengenai jenis pekerjaan yang dilakukan. Mazhab Maliki mensyaratkan supaya pekerjaan yang mereka lakukan harus sejenis dan setempat, sedangkan mazhab Hanafi dan mazhab Hanbali tidak mensyaratkan itu. Adapun mazhab Syafi'i berpendapat bahwa shirkah abdān tidak boleh (Al-Zuhaylī, 2007: 799).

Keempat, syirkah wujûh, yaitu perkongsian yang dilakukan oleh dua orang atau lebih tanpa modal melainkan mendapat kepercayaan orang untuk membeli barang-barang apa saja dengan cara kredit, kemudian menjual lagi dengan mendapat keuntungan dan keuntungan itu dibagi menurut perjanjian waktu perkongsian dibentuk. Disepakati boleh kecuali mazhab Syafi'i. Dalam kitab Bidāyah al-Mujtahid diterangkan bahwa alasan Imam Syāfi'ì tidak membolehkan shirkah wujūh karena perkongsian menghendaki adanya percampuran harta atau modal, sedangkan pada perkongsian kepercayaan tidak ada modal.

Kelima, syirkah mudhârabah, yaitu perkongsian yang diadakan antara orang yang mempunyai modal dan orang yang tidak mempunyai modal, dengan cara orang yang mempunyai modal menyerahkan modalnya kepada orang yang tidak mempunyai modal untuk diusahakan atau berdagang. Disepakati tentang bolehnya shirkah ini oleh Imam mazhab. Adapun mazhab Syaf'i dan mazhab Maliki tidak menggolongkannya ke dalam keadaan shirkah (Sâbiq, 1987: 198).

Dari beberapa shirkah di atas, terdapat perbedaan pendapat mengenai bentuk shirkah yang lebih mendekati kepada pengertian harta bersama. Menurut Ismail Muhamad Syah, pencaharian bersama suami istri lebih dekat pada pengertian syirkah abdān dan shirkah mufāwadah. Dikatakan shirkah abdān karena pada umunya suami istri dalam masyarakat Indonesia sama-sama membanting tulang untuk kehidupan rumah tangga. Adapun dikatakan shirkah mufäwadah karena memang perkongisan suami istri itu tidak terbatas. Apa saja yang mereka hasilkan selama perkawinan menjadi harta bersama kecuali yang mereka terima sebagai warisan atau sebagai pemberian khusus salah seorang di antara mereka berdua (Ismuha, 1986: 296). 
Harta bersama terbentuk bersamaan dengan terjadinya perkawinan kecuali para pihak menentukan lain dalam perjanjian kawin berupa pemisahan harta. Hal ini tercermin dalam pasal 35 Undang-Undang Perkawinan yang menegaskan bahwa harta benda yang diperoleh selama perkawinan menjadi harta bersama (Harahap, 1997: 299).

KHUPer juga mengatur tentang kapan terbentuknya harta bersama dalam pasal 119 menyebutkan bahwa sejak saat dilangsungkannya perkawinan, maka menurut hukum terjadi harta bersama menyeluruh antara suami isteri, sejauh tentang hal itu tidak diadakan ketentuanketentuan lain dalam perjanjian perkawinan.

Dengan demikian, harta apapun yang diperoleh terhitung sejak saat dilangsungkan akad nikah sampai putusnya pernikahan, baik karena perceraian maupun kematian, maka seluruh harta tersebut dengan sendirinya menjadi harta bersama tanpa melihat dari siapa harta tersebut diperoleh. Pengecualian terhadap harta bersama, apabila harta tersebut berupa warisan, wasiyat atau hibah yang diterima oleh salah satu pihak. Harta tersebut dihitung sebagai harta pribadi masingmasing pihak dan dikuasai penuh olehnya.

Realitas kehidupan masyarakat Indonesia yang masih rendah pemahaman hukumnya terhadap masalah hukum. Salah satunya adalah masalah harta bersama. Banyak masyarakat Indonesia yang menganggap bahwa harta kekayaan yang ada dalam perkawinan secara otomatis menjadi harta bersama. Pemahaman itu dilatarbelakangi anggapan bahwa dengan terjadinya akad nikah, maka hal tersebut mempersatukan suami istri dalam seluruh aspek, termasuk masalah harta bersama. Padahal kenyataannya harta kekayaan dalam perkawinan meliputi harta bawaan, harta pribadi dan harta bersama yang satu sama lain mempunyai status hukum yang berbeda.

Mengenai harta bersama sendiri, masih perlu untuk mengklasifikasikan secara jelas mana yang menjadi objek harta bersama dan mana yang bukan. Oleh karena itu, untuk mengetahui bagaimana cara menentukan obyek harta bersama suami isteri dalam perkawinan, perlu digambarkan mengenai ruang lingkup harta bersama. Menurut UU No.1 Tahun 1974 dan KHI ditegaskan bahwa yang menjadi obyek dari harta bersama hanya terbatas harta yang diperoleh selama perkawinan. 


\section{Ketentuan Pembagian Harta Bersama}

Mengenai ketentuan pembagian harta bersama UU No.1 Tahun 1974 tentang Perkawinan tidak mengatur secara jelas tentang ketentuan pembagian harta bersama. Dalam pasal 37 UU No.1 Tahun 1974 menyebutkan bahwa bila perkawinan putus karena perceraian, harta bersama diatur menurut hukumnya masing-masing. Yang dimaksud dengan hukumnya masing-masing ditegaskan dalam penjelasan pasal 37 itu sendiri yaitu hukum agama, hukum adat dan hukum lainnya.

Adapun dalam Kompilasi Hukum Islam diatur secara jelas mengenai porsi pembagian harta bersama. Diantaranya yaitu ketentuan pembagian harta bersama yang berkaitan dengan terjadinya perceraian, kematian salah satu pihak, bagian cerai mati tanpa anak, bagian cerai mati ada anak dan pembagian dalam perkawinan poligami.

\section{Pembagian dalam Cerai Hidup}

Penerapan hukum Islam dalam pembagian harta bersama, baik cerai mati atau cerai hidup, sudah mendapat kepastian hukum. KHI yang tertuang dalam Inpres No.1 Tahun 1991 telah mengaturnya dalam pasal 96 dan 97. Secara khusus, pasal 97 berbunyi bahwa janda atau duda cerai hidup masing-masing berhak seperdua dari harta bersama sepanjang tidak ditentukan lain dalam perjanjian perkawinan.

Jadi menurut apa yang dirumuskan dalam KHI, penerapan terhadap pembagian harta bersama masing-masing pihak mendapat setengah merupakan usaha untuk adanya unifikasi hukum sehingga adanya harmonisasi putusan hakim pengadilan agama dalam memutus perkara harta bersama. Pembagian dalam KHI terhadap bagian harta bersama dalam cerai hidup yang dibagi setengah, sama dengan aturan yang terdapat dalam KUHper pasal 128 yaitu bahwa setelah bubarnya harta bersama, kekayaan bersama mereka dibagi dua antara suami dan isteri, atau antara para ahli waris mereka, tanpa mempersoalkan dan pihak mana asal barang-barang itu.

Menurut Yahya Harahap, pendirian yang digariskan dalam KHI sejalan dengan pandangan orientasi makna perkongsian itu sendiri sehingga suami isteri dianggap sebagai pihak dalam perkongsian terhadap harta bersama dan patut untuk mendapatkan hak dan bagian yang sama apabila perkawinaan mereka pecah (Harahap, 1997: 303). 


\section{Pembagian Cerai Mati}

Pasal 96 KHI menyebutkan bahwa apabila terjadi cerai mati maka separuh harta bersama menjadi pasangan yang hidup lebih lama.

Pertimbangan rumusan pasal ini sama dengan pembagian harta bersama dalam hal cerai hidup, yakni akad nikah menyerupai perkongsian dalam bidang muamalat sehingga selama hidup bersama, suami istri saling membangun perekenomian keluarga. Oleh karena itu, masing-masing suami isteri berhak mendapatkan setengah bagian dalam pembagian harta bersama yang dihasilkan selama perkawinan itu. Hanya saja pembagian harta bersama dalam keadaa cerai mati bisa menimbulkan banyak permasalahan yang memerlukan penerapan tersendiri. Permasalahan yang dimaksud antara lain: (1) Cerai mati tanpa anak. Dalam hal cerai mati tanpa ada anak, penerapannya berdasarkan hukum adat terdapat beberapa variasi. Jika suami mati meninggalkan istri tanpa anak maka ada yang berpendapat bahwa harta bawaan suami maupun harta bersama jatuh menjadi warisan janda yang ditinggalkan. Paling tidak si janda berhak untuk menguasai dan menikmati selama dia hidup atau selama dia belum kawin dengan laki-laki lain. (2) Cerai mati ada anak. Dalam putusan Mahkamah Agung Tanggal 08 Agustus 1959 No.258 K/Sip/1959 disebutkan bahwa dalam kasus cerai mati dengan meninggalkan baik isteri maupun anak-anak, dapat menuntut pembagian harta bersama.

\section{Pembagian Harta Bersama dalam Perkawinan Poligami}

Dalam pasal 94 ayat (1) dan (2) KHI dirumuskan mengenai bentuk harta bersama dalam perkawinan poligami yaitu: (1) Harta bersama dari perkawinan seorang suami yang mempunyai isteri lebih dari seorang, masing-masing terpisah dan berdiri sendiri, (2) Pemilikan harta bersama dari perkawinan seorang suami mempunyai isteri lebih dari seorang sebagaimana ayat (1), dihitung sejak berlangsung akad perkawinan yang kedua, ketiga, atau keempat (Harahap, 1997: 312).

Ketentuan pembagian harta bersama dalam perkawinan poligami mempunyai beberapa asas, yaitu: (1) Dalam perkawinan poligami terbentuk beberapa bagian harta bersama. Bagian tersebut tergantung dengan banyaknya isteri dalam perkawinan poligami. Misal, harta bersama bagian isteri pertama, harta bersama bagian isteri kedua, 
dan sebagainya. (2) Terwujudnya harta bersama terhitung mulai perkawinan dilangsungkan. (3) Masing-masing harta bersama terpisah dan berdiri sendiri. Jadi harta bersama antara perkawinan pertama, kedua, dan seterusnya terpisah satu sama lain dan berdiri sendiri (Manaf, 2006: 46-47).

Adapun dalam hal pembagian harta bersama perkawinan poligami tidak ada bedanya dengan perkawinan monogami yaitu dibagi 50\%:50\% antara suami dan isteri setelah terlebih dahulu harta tersebut dipisahkan dari harta bersama isteri yang lain. Hal tersebut bertujuan agar tidak terjadi ketidakjelasan mengenai obyek harta bersama dan untuk menghindari perebutan harta bersama antara isteri yang satu dengan yang lainnya.

\section{Pembagian Harta Bersama Berdasarkan Kontribusi dalam Perkawinan}

Penyeragaman hukum dalam masalah pembagian harta bersama tersebut memang merupakan sebuah komitmen dari upaya unifikasi hukum untuk mengatasi konflik yang mungkin muncul antara para pihak karena adanya pluralisme hukum. Namundemikian, muncul pertanyaanya itu sejauh manakah konsepsi pembagian harta bersama tersebut dapat memenuhi rasa keadilan dalam masyarakat yang heterogen? Terlebih lagi, apakah konsepsi pembagian harta bersama tersebut juga dapat memenuhi rasa keadilan dalam hal hanya salah satu pasangan yang berjasa atau memiliki kontribusi dalam memperoleh harta bersama tersebut.

Seperti telah diuraikan dalam pembahasan sebelumnya, bahwa secara umum pembagian harta bersama ketika perkawinan berakhir akibat perceraian atau kematian salah seorang pasangan menurut hukum positif adalah bahwa masing-masing suami isteri memiliki hak yang sama terhadap harta bersama, yaitu separoh dari harta bersama. Pembagian seperti ini berlaku tanpa harus mempersoalkan siapakah yang berjerih payah untuk mendapatkan harta kekayaan selama dalam perkawinan. Pertanyaan yang muncul kemudian adalah apakah ketentuan tersebut dapat berlaku secara universal untuk semua kasus, ataukah hanya dalam kasus tertentu yang memang dapat mewujudkan rasa keadilan bagi para pihak.

Seiring dengan tuntutan keadaan pada abad modern ini, orang 
sudah semakin mendambakan sebuah sistem hukum dan perangkatperangkatnya yang dapat memenuhi tuntutan mereka. Kemampuan untuk mengembangkan ide-ide Kompilasi Hukum Islam (KHI) terutama seorang ahli hukum Islam atau seorang hakim agama berhadapan dengan masalah-masalah baru dan perubahan pola hidup yang terjadi di masyarakat (Zein, 1993: 29).

Perubahan pola hidup masyarakat terjadi secara perlahan tetapi pasti akan menimbulkan akses cukup besar terhadap timbulnya perubahan nilai-nilai masyarakat. Nilai-nilai yang dulunya sudah mapan mengalami pergeseran dan mengambil bentuknya yang baru demikian seterusnya. Misal, dahulu jika seorang isteri berkerja mencari nafkah membantu keluarga dapat menimbulkan citra buruk di mata masyarakat. Tetapi sekarang hal itu merupakan hal yang biasa akibat tuntutan dan perubahan zaman. Ekonomi keluarga tidak hanya menjadi monopoli laki-laki atau suami, melainkan juga isteri. Para isteri tidak hanya duduk di rumah dan melayani kebutuhan suami, melainkan juga bergulat dengan usaha dan kerja-kerja ekonomi, sosial, politik dan sebagainya.

Penghasilan ekonomi isteri juga tidak sekedar menjadi sumber ekonomi tambahan atau sampingan bahkan bisa jadi menjadi sumber pokok atau utama. Khusus di daerah perkotaan saat ini semakin banyak terjadi penghasilan isteri justru menjadi tumpuan ekonomi keluarga temasuk suaminya. Dengan begitu isteri mempunyai beban ganda (double burden) sebagai ibu rumah tangga dan pencari nafkah. Hal tersebut menjadikan ketimpangan kontribusi antara suami isteri dalam suatu rumah tangga. Oleh karena itu jelas bahwa telah terjadi perubahan besar antara kebudayaan lama dengan kebudayaan baru, antar bangunan sosial lama dengan bangunan sosial abad sekarang. Maka tidaklah proporsional apabila hukum lama diterapkan dalam struktur sosial baru.

Sejauh pemahaman penulis, ketentuan pembagian harta bersama seperdua bagi suami dan seperdua bagi isteri hanya sesuai dengan rasa keadilan dalam hal baik suami maupun isteri sama-sama melakukan kontribusi yang dapat menjaga keutuhan dan kelangsungan hidup keluarga. Dalam ha ini, pertimbangan bahwa suami atau isteri berhak atas separoh harta bersama adalah berdasarkan peran yang dimainkan baik oleh suami atau isteri, sebagai patner yang saling melengkapi 
dalam upaya membina keutuhan dan kelestarian keluarga.

Dalam hal isteri tidak bekerja di luar, tetapi dia masih memiliki peran besar dalam menjaga keutuhan dan kelangsungan keluarga, seperti mengurusi urusan rumah tangga, mengantar dan menjemput anak, berbelanja dan menyediakan kebutuhan suami, dan lain sebagainya, maka isteri tersebut layak untuk mendapatkan hak separoh harta bersama. Karena status isteri yang berkerja di rumah sebagai ibu rumah tangga sama pentingnya dengan status suami bekerja di luar rumah tangga. Perannya sebagai ibu rumah tangga memberi kontribusi penting dalam proses penciptaan harta bersama suami isteri selama pernikahan mereka, tanpa mempersoalkan atas nama siapa harta tersebut terdaftar (Salim, 2009: 72).

Sebaliknya, ketika isteri bekerja, sedangkan pihak suami tidak menjalankan peran yang semestinya sebagai patner isteri, si suami tidak ikut banting tulang dan tidak pula mengurus rumah tangga, pembagian harta bersama separoh bagi isteri dan separoh bagi suami tersebut tidak sesuai dengan rasa keadilan. Dalam hal ini bagian isteri harus lebih banyak dari pihak suami. Dalam kasus ini dapat digunakan teori keadilan distributif (justisia distributive) bahwa keadilan adalah memberikan bagian kepada setiap orang di dasarkan atas jasa-jasanya atau kontribusinya (Kansil, 1989: 42).

Dalam arti bahwa pihak isteri mempunyai jasa atau kontribusi yang lebih banyak dari suami maka ia berhak mendapatkan dua-pertiga dari harta bersama dan pihak suami hanya sepertiga harta bersama. Bahkanketika ternyata pihak suami selama dalam perkawinan justru boros, sering judi maupun mabuk, maka tidak sepantasnya suami tersebut mendapatkan hak dalam pembagian harta bersama.

Berdasarkan hal tersebut adanya reinterpretasi masalah-masalah hukum keluarga di dalam Kompilasi Hukum Islam terutama mengenai pembagian harta bersama perlu mendapatkan apresiasi sehingga baik isteri maupun suami mendapatkan hak-haknya secara adil karena pilar utama hukum adalah keadilan (Salim, 2009: 74). Berdasarkan itu pula maka pembagian harta bersama berdasarkan kontribusi sangat perlu untuk diapresiasi dalam rangka penegakkan prinsipi-prinsip keadilan yang proporsional antara suami dan isteri di mata hukum. 


\section{Pandangan Hakim Pengadilan Agama Bukit Tinggi Mengenai Pengaruh Kontribusi dalam Perkawinan terhadap Pembagian Harta Bersama}

Setiap putusan hakim memiliki kekuatan hukum yang harus ditaati oleh semua pihak. Pedoman bagi seorang hakim dalam mengambil sebuah keputusan pada sebuah perkara tentunya berdasarkan pada legal justice dengan menempatkan hukum sebagai hukum. Selain itu juga dikenal dengan procedural justice yang memperhatikan terhadap aspek moralitas yang menggambarkan terhadap nilai-nilai keadilan dengan didasarkan kepada kebijaksanaan dan kearifan hakim dalam mengambil keputusan.

Berdasarkan hasil wawancara penulis dengan salah seorang hakim Pengadilan Agama Bukit Tinggi bahwa Hakim Pengadilan Agama dalam menyelesaikana kasus harta bersama merujuk kepada nasnas Alquran, Undang-Undang Nomor 1 Tahun 1974, Yurisprudensi Mahkamah Agung Republik Indonesia dan Kompilasi Hukum Islam sebagai hukum terapan dan hukum positif di pengadilan agama.

Dalam masalah pembagian harta bersama, hakim pengadilan agama biasanya menerapkan ketentuan pasal $97 \mathrm{KHI}$ yang berbunyi bahwa janda atau duda cerai masing-masing berhak seperdua dari harta bersama sepanjang tidak ditentukan lain dalam perjanjian perkawinan.

Menurut hakim yang penulis wawancarai bahwa hakim pengadilan agama dapat mengesampingkan ketentuan Kompilasi Hukum Islam pasal 97 apabila dalam persidangan ditemukan faktafakta yang dapat menjadi pertimbangan hakim dalam memutus perkara tersebut, yaitu mengenai kontroibusi dalam perkawinan.

Dalam memeriksa perkara hakim harus melihat selama hidup berumah tangga siapa yang memberikan kontribusi yang lebih besar. Maka pihak yang lebih besar kontribusinya berhak mendapatkan bagian yang lebih besar.

Mengenai pasal 97 Kompilasi Hukum Islam tentang pembagian harta bersama ada filosofinya yaitu bahwa suami mencari nafkah merupakan kewajibannya sebagai kepala keluarga dan isteri mengurus rumah tangga juga merupakan kewajibannya sehingga pekerjaan isteri tersebut dihitung juga sebagai kontribusi. Hal ini berbeda apabila isteri yang mencari nafkah karena pada dasarnya penghasilan isteri hanya 
sekedar membantu saja bukan sebagai tulang punggung keluarga.

Apabila dalam rumah tangga itu isteri yang mencari nafkah sedangkan suami memberikan kontribusi yang kurang maka sudah seyogyanya porsi isteri dalam harta bersama lebih besar dari suami. Begitu juga apabila suami sudah membanting tulang untuk mencari nafkah sedangkan isteri tidak mengurus rumah tangga dengan benar bahkan berbuat serong atau nusyuz maka sudah semestinya bagian suami dalam harta bersama lebih besar dari isteri.

Dalam perkara harta bersama yang saya (hakim ) putus, bahwa dalam perkara tersebut selama perkawinan si isteri dialah yang aktif berkerja. Isteri sebagai PNS, dia yang memenuhi kebutuhan rumah tangga, meminjam bank untuk membeli tanah, menjual emasnya, bahkan membeli toko untuk suaminya. Padahal bekerja untuk mencari uang bukanlah beban isteri tapi suami berdasarkan Q.s. al-Nisâ [4]: 34 yang menegaskan bahwa laki-laki itu sebagai pelindung perempuan (isteri) karena Allah telah melebihkan laki-laki dari perempuan dan karena laki-laki memberikan nafkah dari hartanya terhadap perempuan (isteri). Dengan begitu apabila kontribusi isteri lebih besar dari suami, maka isteri berhak porsi bagian yang lebih besar dari suami.

Oleh sebab itu apabila hakim tetap menerapkan ketentuan pasal 97 Kompilasi Hukum Islam tentang pembagian harta bersama, sedangkan hanya salah satu pihak yang berjuang mati-matian dalam mengumpulkan harta bersama tetapi pihak lain tetap mendapatkan hak yang sama dengan pihak yang mempunyai kontribusi lebih. Maka putusan tersebut jauh dari nilai keadilan, padahal putusan yang berkualitas adalah putusan yang dapat menimbulkan rasa keadilan di masyarakat dengan mengingat hukum adalah nilai-nilai yang hidup di masyarakat.

Dengan demikian, kontribusi dalam perkawinan dapat mempengaruhi terhadap pembagian harta bersama. Bedanya kontribusi suami dan isteri selama perkawinan dapat menjadi petimbangan hakim untuk memutus masalah sengketa harta bersama. Dari putusan yang ada dalam kasus yang terjadi antara penggugat (suami) dengan tergugat (isteri), dimana hakim Pengadilan Agama Bukit Tinggi yang memutus perkara tersebut membagi $1 / 3$ untuk Penggugat (suami) dan $2 / 3$ untuk Tergugat (isteri). 
Harta bersama tersebut sebagian besar didapat dari hasil kerja keras Tergugat dalam pengelolaan dan perkembangan harta tersebut. Sedangkan Tergugat kurang aktifitasnya dalam pengelolaan dan pengembangan usaha tersebut. Oleh karenanya, menurut penulis, dipandang proporsional dan adil apabila terhadap harta bersama tersebut dibagi berdasarkan seberapa banyak kontribusinya dalam menghasilkan harta bersama tersebut, yakni: 1/3 (sepertiga) untuk Penggugat (suami) dan 2/3 (duapertiga) untuk Tergugat (istri).

Dalam Kompilasi Hukum Islam (KHI) Pasal 88 dinyatakan bahwa apabila terjadi perselisihan antara suami isteri tentang harta bersama, maka penyelesaian perselisihan itu diajukan kepada Pengadilan Agama. Adapun norma hukum yang mengatur harta bersama apabila terjadi perceraian, khususnya cerai hidup diatur dalam Kompilasi Hukum Islam (KHI) Pasal97 yang menyatakan bahwa janda atau duda cerai hidup masing-masing berhak seperdua dari harta bersama sepanjang tidak ditentukan lain dalam perjanjian perkawinan.

Adapun putusan Pengadilan Agama Bukit Tinggi seolah-olah bertentangan dengan Pasal 97 KHI di atas yang tidak memutuskan membagi harta bersama masing-masing antara suami dan isteri berhak seperdua (1/2). Bahkan Pengadilan Agama Bukit Tinggi memutuskan dalam pembagian harta bersama tersebut, yaitu $1 / 3$ untuk suami dan $2 / 3$ untuk isteri, dengan pertimbangan hukum sejauh mana kontribusi masing-masing dalam membentuk harta bersama tersebut.

Dalam hal kasus ini ternyata isteri lebih besar kontribusinya dalam menghasilkan hartabersama tersebut, sehingga menurut penulis wajar apabila bagian isteri lebih besar (2/3) dibanding bagian suami (1/3).

Penulis berargumen bahwa pengadilan dalam membuat putusan selalu diawali dengan "Demi Keadilan Berdasarkan Ketuhanan Yang Maha Esa”. Menurut penulis yang ditegakkan oleh pengadilan adalah "keadilan" bukan "demi hukum". Ada perbedaan antara "demi keadilan" dengan "demi hukum", sebab ruh hukum adalah keadilan. Keadilan dalam hal ini dimaknai memberikan kepada setiap orang apa yang menjadi haknya. Dalam teori ilmu hukum dikenal dengan keadilan distributif, yaitu memberikan kepada setiap orang apa yang menjadi haknya berdasarkan kepada jasa-jasanya atau kontribusinya.

Dalam praktik pengadilan agama, untuk melihat kasus yang beragam, 
maka pertama-tama hakim akan mendudukkan dahulu pokok perkaranya atau kasusnya. Setelah itu hakim akan melihat bagaimana hukum materiilnya (seperti Kompilasi Hukum Islam dalam bidang pembagian harta bersama) yang relevan bersifat umum dan khusus, baik yang tertulis maupun yang tidak tertulis untuk diukur dengan kasus tersebut. Kemudian hakim akan menarik kesimpulan sesuai bukti-bukti yang diajukan dan cocok dengan kasus tersebut.

Dalam hal, apabila dalam kasus yang bersifat jarang ditemukan, yang dengan sendirinya membawa konsekuensi pula di segi pembuktiannya. Di sini letak kesulitan dan tanggung jawab hakim dalam menghubungkan fakta-fakta atau peristiwa, mendudukkan kasusnya serta mempergunakan pembuktian dan hukum yang relevan. Dari sini dapat dinyatakan bahwa penerapan hukum kasus di pengadilan agama ternyata memerlukan wawasan hukum Islam yang sangat luas, tidak dan belum mencukupi dengan hanya menguasai hukum materiil Islam dalam perundang-undangan. Tanpa itu, menemukan hukum materiil dalam kasus, besar kemungkinan tidak mencerminkan keadilan hukum menurut Islam.

Aspek filosofis dalam pembagian harta bersama yang diajukan di pengadilan agama tidak dapat dilepaskan dari aspek keadilan. Keadilan merupakan tujuan hukum Islam dan banyak dalam Alquran untuk menyuruh berbuat dan menegakkan keadilan. Sifat adil yang terkait erat dengan prinsip keadilan dalam hukum keluarga termasuk dalam pembagian harta bersama merupakan hal yang fundamental.

Hukum pembagian harta bersama dalam Kompilasi Hukum Islam (KHI) termasuk hukum yang bersifat mengatur dalam fungsi undangundang yang bersifat deduktif, tekstual dan normatif. Sedangkan perkara pembagian harta bersama yang diajukan kepada hakim agama bersifat kasuistis, induktif, kontekstual dan empiris, yang disebut hukum kasus. Perubahan konteks sosio-historis aktual dalam pembagian harta bersama merupakan keniscayaan, karena kehidupan sosial ini dinamis, dan selalu berubah. Akibatnya hukum selalu ketinggalan dari perubahan itu sehingga timbul permasalahan hukum antara teks dan kontekstual. Berkaitan dengan kasus di atas, demi terciptanya keadilan maka hakim dapat bertindak contra legem.

Contra legem adalah putusan hakim pengadilan yang mengesampingkan peraturan perundang-undangan yang ada sehingga 
hakim tidak menggunakan sebagai dasar pertimbangan atau bahkan bertentangan dengan pasal undang-undang sepanjang pasal undangundang tersebut tidak lagi sesuai dengan perkembangan dan rasa keadilan masyarakat. Hal tersebut dibolehkan sebagai dasarnya adalah UU No.4 tahun 2004 pasal28 (1) yaitu bahwa hakim wajib menggali, mengikuti dan memahami nilai-nilai hukum dan rasa keadilan yang hidup dalam masyarakat. Sedang pasal 2 ayat (1) UndangUndang Nomor 48 Tahun 2009 tentang Kekuasaan Kehakiman yang menyatakan bahwa peradilan dilakukan demi keadilan berdasarkan Ketuhanan Yang Maha Esa. Demikian juga pada pasal 229 KHI mengemukakan bahwa hakim dalam menyelesaikan perkara-perkara yang diajukan kepadanya, wajib memperhatikan sungguh-sungguh nilai-nilai hukum yang hidup dalam masyarakat sehingga putusannya sesuai dengan rasa keadilan.

Menurut pasal $97 \mathrm{KHI}$, janda dan duda mendapat separoh bagian dari harta bersama. Akan tetapi dalam perkara Nomor 618/Pdt. g/2012/ PA.Bt mengingat kelakuan Penggugat (suami) pertanggungan jawab terhadap Tergugat (isterinya) sangat minim sekali serta pemenuhan kebutuhan nafkah lahir maupun batin terhadap isterinya tidak dipenuhi bahkan isterilah yang aktif berkerja. Tentu hal tersebut memberikan beban ganda terhadap isteri, selain sebagai sumber pencari nafkah juga sebagai ibu rumah tangga. Padahal semestinya tanggung jawab mencari nafkah adalah kewajiban seorang suami.

Selain itu, dalam perolehan harta bersama sangat terlihat kecilnya kontribusi Penggugat (suami) bahkan terlihat sekali sikap acuh tak acuh suami. Hal ini terlihat dalam perolehan harta bersama berupa tanah terlihat tergugat (isteri) sendiri yang membayar cicilannya sampai lunas, dan setengah dari uang mukanya. Dalam pembangunan rumah, Tergugat (isteri) yang membangun dengan uang hasil pinjaman koperasi, gaji tergugat sebagai PNS, dan uang tabungan tergugat. Sedangkan Penggugat (suami) tidak memberikan uang untuk membeli bahan bangunan. Begitu juga harta bersama berupa toko Tergugatlah (isteri) yang memberikan modal dagangan dari pinjaman koperasi yang kemudian dicicil dengan gaji Tergugat. Adapun Penggugat (suami) tidak mau tahu tentang utang dari pinjaman koperasi yang dilakukan oleh Tergugat (isteri) untuk membeli tanah, membangun rumah dan toko. 
Dalam kasus seperti ini, menurut hemat penulis, tidak adil jika harta besama antara Penggugat (Suami) denganTergugat (Isteri) dibagi dua sama banyak. Oleh karena itu, hakim diperkenankan untuk melakukan cotra legem sehingga yang tepat dan adil pembagian harta bersamanya adalah 1/3 untuk Penggugat (Suami) dan 2/3 Tergugat (Isteri).

Apabila kita lihat dalam kaidah-kaidah hukum Islam lapangan ijtihad bagi para mujtahid atau termasuk di dalamnya adalah hakim adalah jika dalam Kitabullah (Alquran) dan Sunah (Hadis) tidak diaturnya mengena suatu perkara tertentu, atau sudah ada namun masih bersifat zhony (kurang jelas) atau tidak sesuainya suatu hukum dengan perkara tertentu karena terjadinya perubahan sosio-historis di masyarakat, maka hal itu celah sekaligus merupakan tugas bagi mujtahid untuk berijtihad mencari sehingga menemukan aturan hukumnya (rechtsvinding).

Sebagaimana dituturkan pada sejarahIslam, bahwa telah tejadi pada zaman Rasullullah Saw, Muadz bin Jabal diutus oleh Rasulullah Saw menjadi hakim untuk bertugas ke Yaman. Hal itu telah termaktub dalam Hadis Rasullullah Saw sebagai berikut:

Bahwasannya pada saat mengutus Muadz ke Negeri Yaman, Rasulullah Saw bertanya (kepada Muadz bin Jabal): "Bagaimana cara kamu memutus jika datang kepadamu suatu perkara? Ia menjawab: "Saya putusi dengan (hukum) yang terdapat dalam kitab Allah". Beliau bertanya: "Jika tidak kamu dapati (hukumitu) dalam kitab Allah?", Ia menjawab: "Maka dengan Sunah Rasulullah Saw". Beliau bertanya: "Jika tidak kamu dapati dengan Sunah Rasulullah Saw, juga dalam kitab Allah? Ia menjawab: "Saya akan berijtihad dengan pikiran dan saya tidak akan lengah". KemudianRasullullah Saw menepuk dadanya dan bersabda: "Segala puji bagi Allah yang telah memberi taufiq kepada utusanRasullah Saw yang diridlai oleh Rasulullah”.(H.R. Abu Daud).

Dari Hadis tersebut dapat dipahami bahwa hakim harus menggali dengan pikirannya untuk menemukan hukum dalam menangani kasus yang ditanganinya, sehingga dapat memutus dengan putusanyang adil.

Hakim tidak hanya "labauchedelaloi" (corong undang-undang), bahwa hakim dituntut untuk memiliki keberanian mengambil putusan yang berbeda dengan normatif undang-undang, namun hakim juga dikenal dengan sebutan judge made law. Hal itu tujuannya adalah untuk memberikan keadilan bagi pencari keadilan. Louis L 
Jaffe dalam English and American Judges as Law Maker menyebutkan bahwa hakim yang besar adalah besar, karena manakala keadaan dan peristiwa menjerit-jerit meminta hukum yang baru, maka hakim itu berani membuat dan menciptanya.

Oleh sebab itu putusan Hakim Pengadilan Agama Bukit Tinggi yang melakukan contra legem dengan membagi harta bersama berdasarkan kontribusi dalam perkawinan patut diapresiasi sehingga memberikan keadilan kepada para pihak.

\section{Penutup}

Pembagian harta bersama berdasarkan kontribusi adalah pembagian harta bersama dengan menilai besaran kontribusi para pihak. Dalam arti jika pihak isteri mempunyai jasa atau kontribusi yang lebih banyak dari suami maka ia berhak mendapatkan duapertiga dari harta bersama dan pihak suami hanya sepertiga harta bersama. Dalam Putusan Hakim Pengadilan Bukit Tinggi Nomor 618/Pdt. g/2012/PA.Bt memutuskan harta bersama dibagi dengan ketentuan 1/3 (satupertiga) bagian untuk Penggugat (suami) dan 2/3 (duapertiga) bagian lagi adalah hak Tergugat (isteri). Berdasarkan wawancara penulis dengan hakim bahwa Hakim Pengadilan Agama dapat mengesampingkan ketentuan Kompilasi Hukum Islam pasal 97, apabila dalam persidangan ditemukan fakta-fakta yang dapat menjadi pertimbangan hakim dalam memutus perkara tersebut, yaitu mengenai kontribusi dalam perkawinan. Dalam memeriksa perkara hakim harus melihat selama hidup berumah tangga siapa yang memberikan kontribusi yang lebih besar. Maka pihak yang lebih besar kontribusinya berhak mendapatkan bagian yang lebih besar.

Hakim tidak hanya "labauchedelaloi" (corong undang-undang), tetapi juga dituntut untuk memiliki keberanian mengambil putusan yang berbeda dengan normatif undang-undang apabila hukum tersebut sudah tidak sesuai dengan perubahan sosial di masyarakat. Dalam perkara harta bersama yang salah satu pihak mempunyai kontribusi yang lebih besar hakim diperkenankan untuk melakukan cotra legem sehingga secara kasuistis tidak harus masing-masing mendapat bagian 50\%, mungkin duda mendapat $25 \%$ dan janda $75 \%$ atau berapapun, asal majelis hakim telah mempertimbangkan dengan matang dan "demi keadilan" untuk kedua pihak tersebut. 
Adapaun sebagai bahan pertimbangan penulis memberikan wacana porsi harta bersama dari hasil wawancara penulis dengan salah satu hakim pengadilan agama Bukit Tinggi, menjadi tiga klasifikasi, yaitu: (1) Jika si suami bekerja mencari nafkah dan isteri menjalankan kewajibannya mengurus rumah tangga, mengabdikan dirinya untuk sang suami selama siang malam, merawat mendidik dan menjaga anak maka pekerjan isteri tersebut juga dihitung sebagai kontribusi yang sama dengan pekerjaan suami di luar rumah. Apabila terjadi perceraian maka isteri dan suami berhak $1 / 2$ harta bersama. (2) Jika si suami berkerja mencari nafkah dan isteri tidak menjalankan kewajibannya mengurus rumah tangga, tidak melayani suami, mendidik anaknya, bahkan melakukan nusyuz terhadap suami, berarti isteri tidak memberikan kontribusi yang seimbang dengan suami. Apabila terjadi perceraian maka suami berhak mendapatkan bagian lebih besar dari si isteri. Bisa untuk suami $2 / 3$, atau $3 / 4$, sedangkan untuk isteri hanya $1 / 3$, atau $1 / 4$. (3) Jika yang mencari nafkah si isteri bahkan juga mengurus rumah tangga sehingga memberikan beban ganda (double burden) bagi isteri, sedangkan suami tidak menjalankan kewajibannya sebagai pencari nafkah, malah tidak mau tahu tentang keuangan rumah tangga dan bahkan pemabuk, penjudi. Apabila terjadi perceraian maka isteri berhak mendapatkan bagian lebih besar dari si suami. Bisa untuk isteri $2 / 3$ atau $3 / 4$ sedangkan untuk suami hanya $1 / 3$, atau $1 / 4$. []

\section{Pustaka Acuan}

Arifin, Bustanul, Pelembagaan Hukum Islam di Indonesia, Akar Sejarah Hambatan dan Prospeknya, Jakarta: Gema Insani Press, 1996.

Hakim, Rahmat, Hukum Perkawinan Islam, cet 1, Bandung: Pustaka Setia, 2000. Harahap, M. Yahya, Kedudukan Kewenangan dan Acara Peradilan Agama, Undangundang N0. 7 Tahun 1989, Jakarta: Pusat Kartini, 1997.

Huda, Nurul dan Muhamad Heykal, Lembaga Keuangan Islam, Tinjauan Teoritis dan Praktis, Jakarta : Kencana, 2010.

Ismuha, Pencaharian Bersama Suami Istri, Ditinjau Dari Sudut Undang-undang Perkawinan 1974 dan Hukum Adat, Jakarta: Bulan Bintang, 1986.

Kansil, CST, Pengantar Ilmu Hukum Dan Tata Hukum Indonesia, Jakarta: Balai Pustaka,1989.

Manaf, Abdul, Aplikasi Asa Equalitas Hak dan Kedudukan Suami Isteri dalam Perjanjian Harta Bersama pada Putusan Mahkamah Agung, Bandung, Mandar Maju, 2006. 
Mulyo, Moh. Idris, Tinjauan Beberapa Pasal UU No 1 Tahun 1974 dari Segi Perkawinan Islam, Jakarta: IND HIILCO, 1985.

Sabiq, Sayyid, Fiqh Sunah, Bandung: PT. Al Maarif, 1987.

Salim, Arskal dan Euis Nurlaelawati, Demi Keadilan dan Kesetaraan, Sentivitas Jender Hakim Agama di Indonesia, Jakarta: PUSKUMHAM, 2009.

Satrio, J., Hukum Harta Perkawinan,Bandung : PT Citra Aditya Bakti,1991.

Thalib, Sayuti, Hukum Keluargaan Indonesia, Jakarta: UI Press, 1986.

Zein, Satria Effendi M., Pendidikan Syari'ah di IAIN dan Pembinaan Sikap Independen dalam Hukum Islam, dalam Mimbar HukumN o.II Tahun.IV, 1993.

Zuhaili, al-, Wahbah, al-Figh al-Islāmiy wa Adillatuhū, Darul Fikr: Beirut, 2007.

M. Beni Kurniawan, Magister Hukum Universitas Indonesia, Jl. Percetakan Negara No. 88 Salemba Jakarta Pusat, Email: benieluchiha92@gmail.com 


\section{互ham}

AHKAM Jurnal Ilmu Syariah (ISSN: 1412-4734/E-ISSN: 2407-8646) is a periodical scientific journal published by Faculty of Sharia and Law of Syarif Hidayatullah State Islamic University Jakarta in collaboration with Indonesian Scientist and Sharia Scholar Association (HISSI). This journal specifically examines the science of sharia and obtains to present various results of current and eminence scientific research. The administrators receive articles as contributions Sharia and Islamic law disciplines from scientists, scholars, professionals, and researchers to be published and disseminated. The article will be situated in a selection mechanism, a review of proved reders, and a strict editing process. All articles published in this Journal are based on the views of the authors, but they do not represent the authors' journals or affiliated institutions.

AHKAM has been accredited based on the determination of Director General of Research Reinforcement and Development, Research, and Technology Ministry of Higher Education of Republic of Indonesia, No. 36/a/E/KPT/2016 (valid until 2021). 